\title{
Drug substance and drug product impurities, now what?
}

\begin{abstract}
An unidentified peak in a drug substance or drug product chromatogram raises many questions. What is the impurity? What is the source of the impurity? How much impurity is there? Can the impurity level be reduced or eliminated? Is the impurity toxic? What do we do now? The answers to these questions are typically provided by scientists in chemistry, manufacturing and controls (CMC) and nonclinical toxicology with the single objective of assuring that unavoidable drug impurities induce no risk or an acceptable level of risk for the intended indication and the stage of development. To help address these issues, the International Council for Harmonisation ( $\mathrm{ICH}$ ) guidelines for impurities in drug substance (Q3A) and drug product (Q3B), and for genotoxic impurities (M7) have been adopted and implemented in the United States, Europe, and many other countries around the world. The guidelines address how impurities in drug substances and drug products should be reported, identified, and/or qualified. This Mini Review offers practical insights regarding drug substance and drug product impurities and next steps for the toxicologist when impurity levels exceed the ICH reporting, identification, and/or qualification thresholds. The information presented is largely derived from the following ICH Harmonised Tripartite Guidelines: Q3A(R2) Impurities in New Drug Substances (October 2006), Q3B(R2) Impurities in New Drug Products (June 2006), and M7(R1) Assessment and Control of DNA Reactive (Mutagenic) Impurities in Pharmaceuticals to Limit Potential Carcinogenic Risk (June 2015) and/or the referenced literature. Insights regarding acceptable amounts of residual solvents and the calculation of permitted daily exposures will be the subject of another review.
\end{abstract}

Keywords: toxicology, pharmaceutical impurities, genotoxic impurities, impurity risk assessment, impurity thresholds, impurity qualification

\author{
Volume 3 Issue I - 2017 \\ William R Kelce,' Kristene E Castle, ${ }^{2}$ \\ Florence M Ndikum-Moffor, ${ }^{2}$ Lavonne M \\ Patton' \\ 'Cardinal Health Regulatory Sciences, USA \\ ${ }^{2}$ Overland Park, Kansas, USA
}

Correspondence: William R Kelce, Cardinal Health Regulatory Sciences, 7400 West I I Oth Street, Ste 300, Overland Park, KS 66210, USA, Tel 91366/2040, Fax 9|345।3846, Email william.kelce@cardinalhealth.com

Received: February 21, 2017 | Published: February 27, 2017

\section{Introduction}

Drug substance impurities and drug product impurities are not the same, and are subject to different regulatory requirements. Impurities in drug substances may include starting materials, intermediates, degradation products, etc. In drug substance purity testing, every peak that appears in the chromatogram should be considered a drug substance impurity, unless proven otherwise (eg, solvent peaks). Drug product impurities are defined as, and limited to, degradation products of the drug substance, and reaction products of the drug substance with excipients or the container-closure system. Impurities in the drug substance versus the drug product have important nuances for $\mathrm{CMC}$ scientists in terms of specific reporting, identification, and control requirements (see the ICH Q3A (R2) ${ }^{1}$ and Q3B (R2) ${ }^{2}$ guidelines). However, for the toxicologist the issue for any impurity that exceeds qualification thresholds is whether sufficient safety information exists, either in completed nonclinical or clinical studies or in the literature, to support continued development or whether the impurity needs to be qualified through the conduct of additional safety studies. Qualification of drug substance and drug product impurities are broadly dependent on the maximum theoretical clinical dose, whereas potential mutagenic impurities must be controlled to levels less than the threshold of toxicological concern based on lifetime exposure. As the program develops, adherence to ICH impurity guidelines is required. Each of these impurity issues are discussed below along with next steps for the toxicologist to address these issues. Sponsors are encouraged to seek qualified experts to help address drug impurity issues.

\section{Drug substance impurities}

Table 1 presents the drug substance impurity thresholds described in ICH Q3A(R2) ${ }^{1}$ which trigger reporting, identification, and qualification requirements. The thresholds are broadly dependent on the daily quantity of drug consumed by the patient with threshold tolerances being lower when the maximum exposure is greater than 2 grams of drug substance per day. As per the ICH Q3A(R2) ${ }^{1}$ guideline, impurities in the drug substance below the qualification threshold levels do not need to be qualified unless the impurity is expected to be unusually toxic or potent (Table 1). Impurities in the drug substance primarily originate during the synthetic process using raw materials, intermediates, and by-products present in the reaction mixture at much lower purity requirements than for the drug substance. Since impurities in the drug substance may not be related to or derived from the drug substance, the impuriites may be more toxic than impurities in the drug product which are related to the active drug substance by definition. When an impurity in the drug substance reaches the qualification threshold level, it is the responsibility of the sponsor to establish the safety of the impurity.

\section{ICH Q3A states}

The level of any impurity present in a new drug substance that has been adequately tested in safety and/or clinical studies would be considered qualified. Impurities that are also significant metabolites present in animal or human studies are generally considered qualified. The guidance suggests that an impurity is considered qualified as long as it was present in the drug substance used in nonclinical and clinical studies at a level equal to or higher than levels found in the marketed 
product(s). ${ }^{3}$ For impurities that need to be qualified, the guidance notes that additional toxicology studies can be avoided by lowering the level of the impurity present in the drug substance to levels below the qualification threshold or by providing safety data from the published scientific literature. If neither option is feasible, empirical toxicology testing will have to be performed to qualify the impurity. Potential issues with impurities are one reason why toxicology studies completed early in the development program are often completed with drug substance of lower purity. This practice increases the chances that any potential impurity will be present in the drug substance and thus considered qualified (in that study) when the drug substance impurity is present at multiples higher than the clinical exposure. The situation with impurities potentially needing qualification also underscores the importance of completing a thorough bioanalytical assessment of each drug substance lot to identify the impurities present and their relative concentration. While a thorough bioanalytical assessment of impurities in early drug lots is rare, sponsors should consider devoting resources to these efforts up-front to have this potentially critical information available. Should impurity issues arise later in the development program, the presence of the impurity and its specific level in the drug substance used in toxicology studies can support immediate qualification. The battery of nonclinical studies typically required for qualification include two genetic toxicology studies (the bacterial reverse mutation [Ames] assay and a chromosomal damage [i.e. mouse lymphoma Thymidine Kinase+/-] assay) and a repeatdose, general toxicity study in the most appropriate species for up to 90 days duration (typically a 28 day rat study would suffice). In addition, other specific toxicity endpoints may be appropriate (ie, embryofetal developmental toxicity study). If the impurity is from a class of compounds known to be particularly toxic or nontoxic, the qualification thresholds may be lowered or raised, respectively. The decision tree for the identification and qualification of drug substance impurities (see Attachment 3 in the ICH Q3A (R2) guideline) should be closely followed and thoroughly discussed with the regulatory authority to resolve drug substance impurity issues. In some cases, it may be simpler to decrease impurity levels to no more than the threshold rather than conducting safety studies.

Table I Drug substance impurity thresholds

\begin{tabular}{llll}
\hline $\begin{array}{l}\text { Maximum } \\
\text { daily } \\
\text { dose }^{\mathrm{a}}\end{array}$ & $\begin{array}{l}\text { Reporting } \\
\text { threshold } \mathrm{b}, \mathrm{c}\end{array}$ & $\begin{array}{l}\text { Identification } \\
\text { threshold }\end{array}$ & $\begin{array}{l}\text { Qualification } \\
\text { threshold }^{\mathrm{c}}\end{array}$ \\
\hline$\leq 2 \mathrm{~g} / \mathrm{day}$ & $0.05 \%$ & $\begin{array}{l}0.10 \% \text { or } \mathrm{I} .0 \mathrm{mg} / \\
\text { day, whichever } \\
\text { is lower }\end{array}$ & $\begin{array}{l}0.15 \% \text { or } 1.0 \mathrm{mg} / \\
\text { day, whichever is } \\
\text { lower }\end{array}$ \\
$>2 \mathrm{~g} /$ day & $0.03 \%$ & $0.05 \%$ & $0.05 \%$ \\
\hline
\end{tabular}

$\mathrm{a}=$ the amount of drug substance administered per day.

$b=$ Higher reporting thresholds should be scientifically justified.

$\mathrm{c}=$ Lower thresholds can be appropriate if the impurity is unusually toxic

Source: ICH Harmonised Tripartite Guideline: Q3A (R2) Impurities in New Drug Substances (October 2006).

\section{Drug Product Impurities}

The ICH Q3B (R2)2 guideline defines impurities in new drug products as degradation products of the drug substance or reaction products of the drug substance with an excipient and/or the containerclosure system. In general, since drug product impurities are related to the drug substance, the impurities are typically considered to be less toxic. The thresholds for reporting, identification, and qualification of impurities in new drug products are more granular than for drug substance impurities and are presented in Table 2. As per the ICH Q3B $(\mathrm{R} 2)^{2}$ guideline, impurities in the drug product below the qualification threshold levels do not need to be qualified unless any impurity is expected to be unusually toxic or potent. The reporting threshold is the level at which an impurity must be reported with the analytical procedures indicated. The identification threshold is the level at which an impurity must be structurally identified. The qualification threshold is the level at which the impurity in the drug product must be qualified for safety. The toxicology studies needed to qualify a drug product impurity follow those cited above for impurities in drug substances. The decision tree for the identification and qualification of drug product impurities (see Attachment 3 in the ICH Q3B(R2) guideline) should be closely followed and thoroughly discussed with the regulatory authority to resolve drug product impurity issues.

Table 2 Drug product impurity thresholds

\begin{tabular}{|c|c|c|}
\hline Threshold & $\begin{array}{l}\text { Maximum } \\
\text { Daily Dose }^{\mathrm{a}}\end{array}$ & Threshold $^{b, c}$ \\
\hline \multirow{2}{*}{ Reporting: } & $\leq \mathrm{Ig} /$ day & $0.10 \%$ \\
\hline & $>$ Ig/day & $0.05 \%$ \\
\hline \multirow{4}{*}{ Identification: } & $<$ Img/day & $\begin{array}{l}\text { I. } 0 \% \text { or } 5 \mu \mathrm{g} \text { TDI, whichever } \\
\text { is lower }\end{array}$ \\
\hline & Img to $10 \mathrm{mg} /$ day & $\begin{array}{l}0.5 \% \text { or } 20 \mu \mathrm{g} \text { TDI, whichever } \\
\text { is lower }\end{array}$ \\
\hline & $>10 \mathrm{mg}$ to $2 \mathrm{~g} /$ day & $\begin{array}{l}0.2 \% \text { or } 2 \mathrm{mg} \text { TDI, whichever } \\
\text { is lower }\end{array}$ \\
\hline & $>2 g /$ day & $0.10 \%$ \\
\hline \multirow{4}{*}{ Qualification: } & $<10 \mathrm{mg} /$ day & $\begin{array}{l}\text { I. } 0 \% \text { or } 50 \mu \mathrm{g} \text { TDI, whichever } \\
\text { is lower }\end{array}$ \\
\hline & $10 \mathrm{mg}$ to $100 \mathrm{mg} /$ day & $\begin{array}{l}0.5 \% \text { or } 200 \mu \mathrm{g} \text { TDI, whichever } \\
\text { is lower }\end{array}$ \\
\hline & $>100 \mathrm{mg}$ to $2 \mathrm{~g} /$ day & $\begin{array}{l}0.2 \% \text { or } 3 \mathrm{mg} \text { TDI, whichever } \\
\text { is lower }\end{array}$ \\
\hline & $>2 g /$ day & $0.15 \%$ \\
\hline
\end{tabular}

TDI:Total Daily Intake.

$\mathrm{a}=$ the amount of drug substance administered per day.

$b=$ Thresholds for degradation products are expressed either as a $\%$ of the drug substance or as TDI of the degradation product. Lower thresholds can be appropriate if the impurity is unusually toxic.

$c=$ Higher thresholds should be scientifically justified.

Source: ICH Harmonized Tripartite Guideline: Q3B (R2) Impurities in New Drug Products (June 2006).

\section{Genotoxic Impurities}

While ICH $\mathrm{Q} 3 \mathrm{~A}(\mathrm{R} 2)^{1}$ and $\mathrm{Q} 3 \mathrm{~B}(\mathrm{R} 2)^{2}$ provide guidance for qualification and control for the majority of the impurities, limited guidance is provided for those impurities that are DNA reactive. For DNA reactive impurities, the ICH M7(R1) ${ }^{4}$ guideline was developed. The focus of the $\mathrm{M} 7(\mathrm{R} 1)^{2}$ guideline is on DNA reactive substances that have a potential to directly cause DNA damage when present at low levels leading to mutations and therefore, potentially causing cancer. This type of mutagenic carcinogen is usually detected in an Ames 
assay. Other types of genotoxicants that are non-mutagenic typically have threshold mechanisms (eg, endocrine active substances) and usually do not pose carcinogenic risk in humans at the level ordinarily present as impurities. Impurities are divided into 5 classes depending on their mutagenic and/or carcinogenic potential. These classes range from known mutagenic carcinogens (Class 1) to compounds with no structural alerts or with sufficient data to demonstrate lack of mutagenic or carcinogenic potential (Class 5). To limit a possible human cancer risk associated with the exposure to potentially mutagenic impurities, the Ames assay is used to assess the mutagenic potential. In addition, structure-based assessments can be useful for predicting bacterial mutagenicity outcomes based upon the established knowledge. There are a variety of approaches to conduct this evaluation, including a review of the available literature and/or computational toxicology assessment. The $\mathrm{ICH}$ recommends that for the latter, a computational toxicology assessment should be performed using two Quantitative Structure-Activity Relationship (QSAR) prediction methodologies that complement each other; one methodology should be expert rule-based, and the second methodology should be statistical-based. Sponsors are encouraged to seek experts qualified to complete these QSAR assessments. Impurities that are known mutagens/carcinogens are to be controlled at or below the compound specific acceptable limits, which are based on a threshold of toxicological concern approach given the intended duration of clinical use. The acceptable daily intake values are presented in Table 3 . If the daily intake of an impurity is above the acceptable intake levels, the impurity should be identified and a stepwise approach can be taken for qualification. Qualification may include genotoxicity assessments based on QSAR assessments and scientific published literature; in some cases more extensive genetic toxicity testing may be required. Ideally, mutagenic impurities should be eliminated by modification of the formulation, synthetic route, starting materials, reactants, or through additional purification.

Table 3 Acceptable daily intake values for mutagenic impurities

\begin{tabular}{|c|c|c|c|c|}
\hline \multirow{2}{*}{$\begin{array}{l}\text { Number of } \\
\text { impurities }\end{array}$} & \multicolumn{4}{|c|}{$\begin{array}{l}\text { Total daily intake ( } \mu \mathrm{g} / \mathrm{day}) \text { by clinical } \\
\text { duration of treatment } \mathrm{t}^{\mathrm{a}}\end{array}$} \\
\hline & $\leq$ IMonth & $\begin{array}{l}>1 \text { to } \\
12 \text { Months }\end{array}$ & $\begin{array}{l}>1 \text { to } \\
10 \text { Years }\end{array}$ & $\begin{array}{l}>10 \text { Years } \\
\text { to } \\
\text { Lifetime }\end{array}$ \\
\hline $\begin{array}{l}\text { Individual or } \\
2 \text { Impurities, Class } 2 \\
\text { or } 3 \text { Mutagenic } \\
\text { Impurities }\end{array}$ & 120 & 20 & 10 & 1.5 \\
\hline $\begin{array}{l}\text { Multiple Impurities }{ }^{\mathrm{a}, \mathrm{b}} \\
\geq 3 \text {, Class } 2 \text { or } 3 \\
\text { Mutagenic Impurities } \\
\text { Total of All } \\
\text { Mutagenic Impurities }\end{array}$ & 120 & 60 & 30 & 5 \\
\hline
\end{tabular}

$\mathrm{a}=$ Impurities that are known mutagens/carcinogens are to be controlled at or below the compound-specific acceptable limits.

$\mathrm{b}=$ If there are 2 class 2 or 3 impurities, individual limits apply. When there are 3 or more class 2 or 3 impurities, the total of all mutagenic impurities should be per the values provided.

Source: ICH Harmonized Tripartite Guideline: M7 (RI) Assessment and Control of DNA Reactive (Mutagenic) Impurities in Pharmaceuticals to Limit Potential Carcinogenic Risk (June 2015).

\section{Key insights}

Recent experience between sponsors and review divisions suggests an increased scrutiny with impurities, where the regulatory authority has stated that any impurity or degradation product that exceeds defined thresholds must be adequately qualified for safety as per $\mathrm{ICH}$ Q3A(R2) ${ }^{1}$ and $\mathrm{Q} 3 \mathrm{~B}(\mathrm{R} 2)^{2}$ guidelines. While the guidelines state that they are not intended to apply during the clinical research stage of development, recent trends suggest that sponsors should follow these guidelines more closely, especially at the latter stages of clinical development. Toxicology studies to establish safety should compare the new drug substance or drug product containing a representative amount of the new impurity with previously qualified test article or using the isolated impurity only. Adequate qualification must include genotoxicity and repeat-dose toxicology studies of appropriate duration to support the proposed indication. In addition, other specific toxicity studies may be appropriate (ie, embryofetal developmental toxicity study). Genotoxic impurities and degradation products pose an additional risk and should be controlled in accordance with the M7(R1) ${ }^{4}$ guidances, unless qualified for safety. Given the apparent increased scrutiny regarding impurities, toxicology programs for molecules early in development should consider using a wellcharacterized drug substance of lower purity. These early toxicology studies will then increase the chances that any particular impurity will be present in the drug substance at levels considered qualified, especially when the drug substance impurity is present at multiples higher than clinical exposure. A thorough bioanalytical assessment of these early "dirty" lots is an additional up-front effort and expense, but knowing the specific impurities present and the relative concentration of each impurity could be critically important and timely should impurity issues arise later in the development program. For 505(b $)^{2}$ applications, impurity levels in the drug product should be below the $\mathrm{Q} 3 \mathrm{~B}(\mathrm{R} 2)^{2}$ qualification threshold or below the level present in the reference listed drug in a side-by-side comparison. Degradation products that are also significant metabolites present in animal and/ or humans may be considered qualified; however, information on the plasma levels should be provided. This information may be based on the label of the listed drug, published articles, or studies conducted using the drug product containing the impurity or the impurity itself. Information in the $\mathrm{FDA}^{5}$ summary basis of approval cannot be used for this purpose. Sponsors are also reminded to use allometric scaling to compare impurity exposures in nonclinical species with impurity exposures in humans. This involves converting the no observed adverse effect level (NOAEL) doses in the most relevant animal species to the human equivalent doses (HED) based on body surface area, recognizing that larger animals typically have lower metabolic rates. Since body surface area varies with body weight $(\mathrm{W})^{0.67}$, the conversion factors are dependent on the weight of the animals in the studies. This dose-by-factor strategy is based on minimum risk of toxicity rather than minimum pharmacologic activity. The most accurate predictions occur for renally excreted compounds with low hepatic metabolism and a low volume of distribution.

\section{Calculating human equivalent dose}

The conversion factors and divisors shown in Table 4 are recommended by the $\mathrm{FDA}^{5}$ as the standard values to be used for interspecies dose conversions for NOAELs. These factors may also be applied when comparing safety margins for other toxicity endpoints (eg, reproductive toxicity and carcinogenicity) when other data for comparison (i.e. area under the concentration versus time curves) are 
unavailable or are otherwise inappropriate for comparison. The HED is determined as follows:

HED $(\mathrm{mg} / \mathrm{kg})=$ Animal NOAEL $(\mathrm{mg} / \mathrm{kg}) \times\left(\right.$ Weight $_{\text {animal }}[\mathrm{kg}] /$ Weight $\left._{\text {human }}[\mathrm{kg}]\right)^{(1-0.67)}$

The correction factor $\left(\mathrm{k}_{\mathrm{m}}\right)$ is estimated by dividing the average body weight $(\mathrm{kg})$ for the species by that species body surface area $\left(\mathrm{m}^{2}\right)$. The $\mathrm{k}_{\mathrm{m}}$ value for each species increases with body weight, but a fixed $\mathrm{k}_{\mathrm{m}}$ factor for each species is preferred for standardization and practical purposes. For example, the average human body weight is $60 \mathrm{~kg}$, and the body surface area is $1.62 \mathrm{~m}^{2}$. Therefore, the $\mathrm{k}_{\mathrm{m}}$ factor for a human is calculated by dividing 60 by 1.62 , which is 37 (Table 4 ).

Table 4 Conversion of animal doses to human equivalent doses based on body surface area

\begin{tabular}{|c|c|c|c|}
\hline \multirow{2}{*}{ Species } & \multirow{2}{*}{$\begin{array}{l}\text { To convert animal dose in } \mathrm{mg} / \mathrm{kg} \text { to dose in } \\
\mathrm{mg} / \mathrm{m}^{2} \text {, multiply by } \mathrm{k}_{\mathrm{m}}\end{array}$} & \multicolumn{2}{|c|}{ To convert animal dose in $\mathrm{mg} / \mathrm{kg}$ to $\mathrm{hed}^{\mathrm{a}}$ in $\mathrm{mg} / \mathrm{kg}$, either } \\
\hline & & Divide animal dose by & Multiply animal dose by \\
\hline Human & 37 & - & - \\
\hline Child & 25 & - & - \\
\hline Mouse & 3 & 12.3 & 0.081 \\
\hline Hamster & 5 & 7.4 & 0.135 \\
\hline Rat & 6 & 6.2 & 0.162 \\
\hline Ferret & 7 & 5.3 & 0.189 \\
\hline Guinea pig & 8 & 4.6 & 0.216 \\
\hline Rabbit & 12 & 3.1 & 0.324 \\
\hline Dog & 20 & 1.8 & $0.54 I$ \\
\hline $\begin{array}{l}\text { Primates: } \\
\text { Monkeys }\end{array}$ & 12 & 3.1 & 0.324 \\
\hline Marmoset & 6 & 6.2 & 0.162 \\
\hline Squirrel monkey & 7 & 5.3 & 0.189 \\
\hline Baboon & 20 & 1.8 & $0.54 I$ \\
\hline Micro-pig & 27 & 1.4 & 0.73 \\
\hline Mini-pig & 35 & I.I & 0.946 \\
\hline
\end{tabular}

HED: Human Equivalent Dose; Km: Scaling Factor; -: Not Applicable.

$\mathrm{a}=$ Assumes $60-\mathrm{kg}$ human. For species not listed or for weights outside the standard ranges, HED can be calculated from the following formula:

HED = animal dose in $\mathrm{mg} / \mathrm{kg} \times($ animal weight in $\mathrm{kg} / \mathrm{human}$ weight in $\mathrm{kg}) 0.33$.

$\mathrm{b}=$ This $\mathrm{Km}$ value is provided for reference only because healthy children will rarely be volunteers for phase I trials.

$\mathrm{c}=$ for example, cynomolgus, rhesus, and stumptail.

Source: FDA Guidance for Industry: Estimating the Maximum Starting Dose in Initial Clinical Trials for Therapeutics in Adult Healthy Volunteers (July 2005).

\section{Sample calculations}

The $\mathrm{k}_{\mathrm{m}}$ factor value for various animal species is used to estimate the HED as follows:

Example 1: Convert an animal or human dose from $\mathrm{mg} / \mathrm{kg}$ to $\mathrm{mg}$ / $m^{2}$ HED

ply dose in $\mathrm{mg} / \mathrm{kg}$ by $\mathrm{k}_{\mathrm{m}}$

Dose of $30 \mathrm{mg} / \mathrm{kg}$ in a $\mathrm{dog}=30 \mathrm{mg} / \mathrm{kgx} 20 \mathrm{~kg} / \mathrm{m}^{2}=600 \mathrm{mg} / \mathrm{m}^{2}$

Dose of $2.5 \mathrm{mg} / \mathrm{kg}$ in a human $=2.5 \mathrm{mg} / \mathrm{kgx} 37 \mathrm{~kg} / \mathrm{m}^{2}=92.5 \mathrm{mg} / \mathrm{m}^{2}$

\section{Example 2: Convert an animal dose from $\mathrm{mg} / \mathrm{kg}$ to $\mathrm{mg} / \mathrm{kg}$ HED}

Divide animal dose by $\mathrm{k}_{\mathrm{m}}$ ratio (human/animal) OR Multiply animal dose by $\mathrm{k}_{\mathrm{m}}$ ratio (animal/human)

HED $(\mathrm{mg} / \mathrm{kg})$ of $50 \mathrm{mg} / \mathrm{kg}$ in rats $=50 \mathrm{mg} / \mathrm{kg} \div 6.2=8 \mathrm{mg} / \mathrm{kg}$

HED $(\mathrm{mg} / \mathrm{kg})$ of $15 \mathrm{mg} / \mathrm{kg}$ in $\operatorname{dogs}=15 \mathrm{mg} / \mathrm{kg} \div 1.8=8 \mathrm{mg} / \mathrm{kg}$

\section{Conclusion}

Drug substance and drug product impurities are a current hot button issue with regulatory authorities. Sponsors are encouraged to master the guidance documents discussed in this mini-review and consult a qualified expert with any questions or for assistance in assessing specific impurity issues. The use of "dirty", but analytically wellcharacterized, drug lots in early toxicology studies is recommended to maximize the opportunity to assess impurity safety early in the drug development process. This approach could potentially save precious time at the latter stages of drug development.

\section{Acknowledgements}

None.

\section{Conflict of interest}

The authror declares no conflict of interest. 


\section{Referecnes}

1. ICH Harmonized Tripartite Guideline: Q3A (R2) Impurities in New Drug Substances. 2006.

2. ICH Harmonized Tripartite Guideline: $Q 3 B(R 2)$ Impurities in New Drug Products. USA; 2006. p. 1-12.

3. Jacobson-Kram D, McGovern T. Toxicological overview of impurities in pharmaceutical products. Adv Drug Deliv Rev. 2007;59(1):38-42.
4. ICH Harmonized Tripartite Guideline: M7(R1) Assessment and Control of DNA Reactive (Mutagenic) Impurities in Pharmaceuticals to Limit Potential Carcinogenic Risk. 2015.

5. FDA Guidance for Industry: Estimating the Maximum Starting Dose in Initial Clinical Trials for Therapeutics in Adult Healthy Volunteers. USA; 2005. p. 1-247. 